\title{
EFFECTS OF MYCORRHIZATION AND PHOSPHORUS NUTRITION ON NUTRIENT UPTAKE, GROWTH AND FLOWERING OF CHINA ASTER (Callistephus chinensis (L.) NEES) CULTIVATED ON EBB-AND-FLOW BENCHES
}

\author{
Joanna Nowak \\ Department of Ornamental Plants, West Pomeranian University of Technology, Janosika 8, 71-424 Szczecin, Poland \\ e-mail: Joanna-Nowak@zut.edu.pl
}

Received: 8.08.2008

\section{Abstract}

The effects were investigated of phosphorus nutrition and $\mathrm{AMF}$ inoculation on nutritional status, growth, and flowering of China aster (Callistephus chinensis (L.) Nees) 'Milady' during cultivation on ebb-and-flow benches. Two P treatments of 8.68 and $43.40 \mathrm{mgxdm}^{-3}$ were applied. One month after inoculation the roots of inoculated plants were infected by mycorrhizal fungi. The control plants had no root infection. The mycorrhizal fungal colonization in plants that were fertilized at 8.68 and $43.40 \mathrm{mg} \times \mathrm{dm}^{-3} \mathrm{P}$ was $67 \%$ and $60 \%$, respectively. Slightly increased $\mathrm{P}$ content was detected in leaves of mycorrhizal plants grown under low P level. Mycorrhization did not affect leaf $\mathrm{P}$ content of plants grown in high P level. Increased $\mathrm{Mg}$ content was measured in leaves of mycorrhizal plants grown under both P levels. Mycorrhizal and nonmycorrhizal plants did not differ with regard to leaf $\mathrm{N}, \mathrm{K}$, and $\mathrm{Ca}$ contents. P nutrition did not also affect the contents of these elements in leaf tissue. Mycorrhization decreased the $\mathrm{pH}$ and lowered salt accumulation in growing media. Significantly lower shoot biomass, plant height, shoot number were recorded in all plants inoculated with AMF. Mycorrhization also delayed flowering of China aster; the high P level slightly accelerated it. Mycorrhizal plants had fewer flower buds and flowers than nonmycorrhizal ones. The high $\mathrm{P}$ level increased the number of flowers of nonmycorrhizal plants only.

Key words: Callistephus chinensis, mycorrhization, phosphorus, nutrient uptake, growth, flowering

\section{INTRODUCTION}

Bedding plants cultivated in greenhouses are often grown in disinfected substrates to lower risk of contamination. Disinfection treatment eliminates arbuscular mycorrhizal fungi (AMF) in growing medium. The mycorrhizal inoculation has the potential to enhance growth and flowering of ornamental plants, particularly in nutrient-deficient soils ( G a u r and A d h o le y a,
2005) or in drought conditions ( $\mathrm{A} \mathrm{u} \mathrm{g} \mathrm{z} \mathrm{,} \mathrm{2000).} \mathrm{Inocu-}$ lation with $\mathrm{AMF}$ during cultivation in greenhouses may be beneficial for further plant growth in outdoor conditions. It was shown earlier that mycorrhization of some bedding plants is significantly reduced by high $\mathrm{P}$ concentration (K o ide et al. 1999). Plant growth responses to AM fungi are found to vary with the host plant and soil (En try et al. 2002).

These studies were designed to test the ability of Glomus species to colonize the root system of China aster during greenhouse cultivation under different $\mathrm{P}$ levels, and to evaluate the effect of mycorrhization and $\mathrm{P}$ level on plant growth, flowering and mineral content of leaves and growing medium.

\section{MATERIALS AND METHODS}

Seeds of China aster (Callistephus chinensis (L.) Nees), dwarf cultivar 'Milady' used as bedding plants, were sown in February. The seedlings $(7-9 \mathrm{~cm}$ high, with 6-8 leaves) were planted into sphagnum peat: perlite substrate $(3: 1, \mathrm{v} / \mathrm{v}), \mathrm{pH} 6.1$, EC $0.4 \mathrm{~m}$ $\mathrm{S} \times \mathrm{cm}^{-1}$. The substrate was inoculated with Endorize - TA AMF inoculum, containing a mixture of different Glomus species (Biorize Sarl, France), as described earlier (N o w a k, 2004 a). The substrate was not sterilized. The peat used in this experiment was devoid of AMF, as confirmed by the absence of colonization with the non-inoculated treatments. Mycorrhizal infection was estimated after staining the roots with trypan blue (Phillips and Hay man, 1970).

Plants were fertigated by subirrigation (ebband-flow benches, Clauhan Project A/S, Denmark). The $\mathrm{P}$ treatments were as follows: 8.68, and 43.40 $\left(\mathrm{mg} \times \mathrm{dm}^{-3}\right)$. The nutrient solutions contained also: $\mathrm{N}-\mathrm{NO}_{3}$ 169.1, K 214.1, Ca 124.0, Mg 18.5, S 35.2, and $\mathrm{B} \mathrm{0.24,} \mathrm{Fe} \mathrm{1.23,} \mathrm{Mn} \mathrm{0.55,} \mathrm{Cu} \mathrm{0.03,} \mathrm{Mo} \mathrm{0.09,}$ Zn $0.20\left(\mathrm{mg} \times \mathrm{dm}^{-3}\right)$, EC (electrical conductivity) be- 
ing $1.8 \mathrm{mS} \times \mathrm{cm}^{-1}$. Potassium nitrate, monobasic potassium phosphate, calcium nitrate, magnesium sulphate, boric acid, iron EDTA, manganese EDTA, copper EDTA, ammonium molybdate, zinc EDTA were used for preparation of nutrient solutions. The nutrient solutions were adjusted to $\mathrm{pH}$ 6.0. There were four sections of benches fertigated separately at each $\mathrm{P}$ level and mycorrhization treatment. The plants were cultivated under glass from the beginning of April to the end of June. All measurements were conducted at the end of the experiment, after 11 weeks of growth.

Whole plants were harvested. Plant height, leaf number, fresh and dry weights of leaves, numbers of flower buds and flowers, mineral nutrient content of leaves and substrates, root colonization by AM fungi were determined.

Leaf nutrient contents were determined for 3 plants per replicate. There were 3 replications per treatment. All mature leaves were sampled. The leaf tissues were oven-dried at $78^{\circ} \mathrm{C}$, milled to homogeneous samples, and then treated with the mixture of $65 \% \mathrm{HNO}_{3}$ and $60 \% \mathrm{HClO}_{4}(3.5: 1, \mathrm{v}: \mathrm{v})$. The concentrations of $\mathrm{K}^{+}, \mathrm{Ca}^{2+}$ and $\mathrm{Mg}^{2+}$ were measured using atomic absorption spectrophotometry (PU 9100X; Philips, Holland), $\mathrm{P}$ was determined colorimetrically by using vanadiummolybdate complex, $\mathrm{N}$ was determined using the Kjeldahl method with an automatic distillation system with boric acid (Kieltec, Tecator, Sweden).

Available macroelements contained in the medium were extracted with acetic acid using the modified Spurway method (N ow o s iels k i, 1989). The concentrations of $\mathrm{K}, \mathrm{Ca}, \mathrm{Mg}$, and $\mathrm{P}$ were determined as described above for leaf samples. $\mathrm{N}-\mathrm{NO}_{3}$ was measured with a nitrate-specific electrode, EC was determined by a conductivity meter (Type OK-1021, Badelkis, Budapest, Hungary).

The experiment employed a split-plot two factorial design. There were 20 pots per treatment, each plant was treated as a replication. The treatments were statistically analyzed by analysis of variance and means were compared with Duncan's multiple range test at $95 \%$ level of significance.

\section{RESULTS AND DISCUSSION}

The mycorrhizal root colonization percentage at the end of the experiment, 11 weeks after inoculation, was rather high in both $\mathrm{P}$ treatments, $67 \%$ for plants that were fertilized at $8.68 \mathrm{mg} \times \mathrm{dm}^{-3} \mathrm{P}$, while for those fertilized at $43.40 \mathrm{mg} \times \mathrm{dm}^{-3} \mathrm{P}$ was $60 \%$. All noninoculated roots remained free of colonization by AMF.

Many studies have shown that mycorrhizal plants have higher shoot $\mathrm{P}$ concentrations than plants with no or reduced AMF colonization when these plants are grown in soils with low $\mathrm{P}$ content. Information on acquisition of the other macronutrients $\mathrm{N}, \mathrm{K}, \mathrm{Ca}, \mathrm{Mg}$ by mycorrhizal plants has been inconsistent, in that increases, no effects, and decreases having been reported (C l a r k and Z e t o, 2000; G e or g e, 2000). In China aster slightly increased $\mathrm{P}$ content was detected in leaves of mycorrhizal plants grown under low $\mathrm{P}$ level (Tab. 1). Mycorrhization did not affect leaf $P$ content of plants grown in high $\mathrm{P}$ level. Increased $\mathrm{Mg}$ content was measured in leaves of mycorrhizal plants grown

Table 1

The effects of mycorrhization with AMF and P level on mineral element content of leaves of Callistephus chinesis 'Milady' cultivated on ebb-and-flow benches.

\begin{tabular}{|c|c|c|c|c|c|c|c|}
\hline \multirow{4}{*}{$\begin{array}{c}\text { Mycorrhization } \\
\text { No AMF }\end{array}$} & \multirow{4}{*}{$\begin{array}{c}\begin{array}{c}\text { P level } \\
\mathrm{mg} \times \mathrm{dm}^{-3}\end{array} \\
8.68 \\
43.40\end{array}$} & \multicolumn{6}{|c|}{ Mineral element content $\left(\mathrm{g} \times \mathrm{kg}^{-1}\right.$ of dry matter $)$} \\
\hline & & \multirow{3}{*}{$\begin{array}{c}\mathrm{N} \\
4.58 \mathrm{a} \\
4.56 \mathrm{a}\end{array}$} & \multirow{3}{*}{$\begin{array}{c}\mathrm{P} \\
0.067 \mathrm{a} \\
0.165 \mathrm{c}\end{array}$} & \multirow{3}{*}{$\begin{array}{c}\mathrm{K} \\
5.4 \mathrm{a} \\
5.7 \mathrm{a}\end{array}$} & \multicolumn{2}{|c|}{$\mathrm{Ca}$} & \multirow{3}{*}{$\begin{array}{l}\mathrm{Mg} \\
0.2 \mathrm{a} \\
0.3 \mathrm{a}\end{array}$} \\
\hline & & & & & 1.1 & a & \\
\hline & & & & & 1.2 & a & \\
\hline \multirow[t]{2}{*}{ AMF } & 8.68 & $4.61 \mathrm{a}$ & $0.078 \mathrm{~b}$ & $5.2 \mathrm{a}$ & \multirow{2}{*}{\multicolumn{2}{|c|}{$\begin{array}{l}1.3 \mathrm{a} \\
1.2 \mathrm{a}\end{array}$}} & $0.4 \mathrm{~b}$ \\
\hline & 43.40 & $4.67 \mathrm{a}$ & $0.168 \mathrm{c}$ & $5.7 \mathrm{a}$ & & & $0.4 \mathrm{~b}$ \\
\hline \multicolumn{8}{|c|}{ Significance (main effects) } \\
\hline Mycorrhization & & n.s. & $* * *$ & n.s. & \multicolumn{2}{|c|}{ n.s. } & $* * *$ \\
\hline P level & & n.s. & $* * *$ & n.s. & \multicolumn{2}{|c|}{ n.s. } & n.s. \\
\hline Myc. x P level & & n.s. & $* * *$ & n.s. & \multicolumn{2}{|c|}{ n.s. } & n.s. \\
\hline
\end{tabular}

Values followed by the same letter are not significantly different according to the Duncan test $(\mathrm{P}<0.05)$ $* * *$, **, n.s. Significant at $\mathrm{P}<0.01, \mathrm{P}<0.05$, not significant, respectively 
under both P levels. Mycorrhizal and nonmycorrhizal plants did not differ with regard to leaf $\mathrm{N}, \mathrm{K}$, and $\mathrm{Ca}$ contents. $\mathrm{P}$ nutrition did not also affect the contents of these elements in leaf tissue.

Mycorrhization slightly decreased the $\mathrm{pH}$ of growing media (Tab. 2). Similar results concerning the effect of AMF on $\mathrm{pH}$ were earlier obtained by other authors (Li et al. 1991). AMF significantly lowered salt accumulation in growing media. $\mathrm{P}$ level did not affect the $\mathrm{pH}$ of growing media, slightly increased total soluble salt content in noninoculated medium, and slightly lowered it in AMF inoculated medium. The lowest $\mathrm{N}$ level was measured in growing medium inoculated with AMF and fertilized with nutrient solution containing less $\mathrm{P}$. A higher $\mathrm{P}$ level increased $\mathrm{P}$ content of growing medium. Mycorrhization and $\mathrm{P}$ level in nu- trient solution did not affect $\mathrm{K}, \mathrm{Ca}$, and $\mathrm{Mg}$ contents of growing medium.

Significantly lower shoot biomass, plant height, shoot number were recorded in all plants inoculated with AMF (Tab. 3). Reduced growth as a result of mycorrhization was also observed in some Tagetes cultivars (Linderman and D a vis, 2004). No effect of root inoculation with Glomus intraradices on shoot biomass was earlier recorded in Callistephus chinensis grown in P-deficient soil under field conditions (Gaur and Adholeya, 2005). It is well known that mycorrhization can depress plant growth primarily by sink competition for photosynthates (D o u d s et al. 1988). Some studies have indicated that plant growth depression due to mycorrhizal colonization is attributed to greater carbon expenditure in a colonized

Table 2

The effects of mycorrhization with AMF and P level on chemical characteristic of growing medium at the end of culture of Callistephus chinesis 'Milady' cultivated on ebb-and-flow benches.

\begin{tabular}{|c|c|c|c|c|c|c|c|c|}
\hline \multirow{2}{*}{ Mycorrhization } & \multirow{2}{*}{$\begin{array}{c}\text { P level } \\
\mathrm{mg} \times \mathrm{dm}^{-3}\end{array}$} & \multirow{2}{*}{$\mathrm{pH}$} & \multirow{2}{*}{$\begin{array}{l}\text { Total soluble } \\
\text { salts } \\
\left(\mathrm{g} \times \mathrm{dm}^{-3}\right)\end{array}$} & \multicolumn{5}{|c|}{ Macroelement content $\left(\mathrm{mgxdm}^{-3}\right)$} \\
\hline & & & & $\mathrm{N}-\mathrm{NO}_{3}$ & $P$ & $\mathrm{~K}$ & $\mathrm{Ca}$ & $\mathrm{Mg}$ \\
\hline \multirow[t]{2}{*}{ No AMF } & 8.68 & $7.3 b$ & $4.9 c$ & $1282 b$ & $65 a$ & $1494 \mathrm{a}$ & $1224 a$ & $175 \mathrm{a}$ \\
\hline & 43.40 & $7.2 b$ & $5.5 \mathrm{~d}$ & $1340 \mathrm{~b}$ & $343 b$ & $1497 \mathrm{a}$ & $1367 \mathrm{a}$ & $184 \mathrm{a}$ \\
\hline \multirow[t]{2}{*}{ AMF } & 8.68 & $6.75 \mathrm{a}$ & $4.15 b$ & $1111 \mathrm{a}$ & $59 a$ & $1415 \mathrm{a}$ & $1211 \mathrm{a}$ & $152 \mathrm{a}$ \\
\hline & 43.40 & $6.75 \mathrm{a}$ & $3.95 \mathrm{a}$ & $1251 b$ & $223 b$ & $1502 \mathrm{a}$ & $1249 \mathrm{a}$ & $169 \mathrm{a}$ \\
\hline \multicolumn{9}{|c|}{ Significance (main effects) } \\
\hline Mycorrhization & & $* * *$ & $* * *$ & $* *$ & n.s. & n.s. & n.s. & n.s. \\
\hline P level & & n.s. & n.s. & $* *$ & $* * *$ & n.s. & n.s. & n.s. \\
\hline Myc. x P level & & n.s. & $* * *$ & $* * *$ & n.s. & n.s. & n.s. & n.s. \\
\hline
\end{tabular}

Explanations as in Table 1

Table 3

The effects of mycorrhization with AMF and P level on growth of Callistephus chinesis 'Milady' cultivated on ebb-and-flow benches.

\begin{tabular}{|c|c|c|c|c|c|c|}
\hline Mycorrhization & $\begin{array}{c}\text { P level } \\
\mathrm{mg} \times \mathrm{dm}^{-3}\end{array}$ & $\begin{array}{c}\text { Shoot } \\
\text { f.w. } \\
\text { (g) }\end{array}$ & $\begin{array}{c}\text { Shoot } \\
\text { d.w. } \\
\text { (g) }\end{array}$ & $\begin{array}{l}\text { Plant } \\
\text { height } \\
(\mathrm{cm})\end{array}$ & Shoot number & Leaf number \\
\hline \multirow[t]{2}{*}{ No AMF } & 8.68 & $66.2 b$ & $13.1 \mathrm{~b}$ & $28.8 b$ & $9.2 \mathrm{~b}$ & $31.0 \mathrm{ab}$ \\
\hline & 43.40 & $71.5 \mathrm{c}$ & $14.4 \mathrm{c}$ & $29.0 b$ & $12.1 \mathrm{c}$ & $29.6 \mathrm{a}$ \\
\hline \multirow[t]{2}{*}{ AMF } & 8.68 & $41.7 \mathrm{a}$ & 7.9a & $27.8 \mathrm{ab}$ & $5.8 \mathrm{a}$ & $32.8 b$ \\
\hline & 43.40 & $43.8 \mathrm{a}$ & $8.5 \mathrm{a}$ & $27.3 \mathrm{a}$ & $6.4 \mathrm{a}$ & $32.7 b$ \\
\hline \multicolumn{7}{|c|}{ Significance (main effects) } \\
\hline Mycorrhization & & $* * *$ & $* * *$ & $* * *$ & $* * *$ & $* * *$ \\
\hline P level & & $* *$ & $* *$ & n.s. & $* * *$ & n.s. \\
\hline Myc. x P level & & n.s. & n.s. & n.s. & $* * *$ & n.s. \\
\hline
\end{tabular}

Explanations as in Table 1 
Table 4

The effects of mycorrhization with AMF and P level on flowering and visual evaluation of Callistephus chinesis 'Milady' cultivated on ebb-and-flow benches.

\begin{tabular}{|c|c|c|c|c|c|}
\hline Mycorrhization & $\begin{array}{c}\text { P level } \\
\mathrm{mg} \times \mathrm{dm}^{-3}\end{array}$ & $\begin{array}{l}\text { Number of days } \\
\text { from planting to } \\
\text { flowering }\end{array}$ & $\begin{array}{c}\text { Flower bud } \\
\text { number }\end{array}$ & Flower number & Visual evaluation $^{1}$ \\
\hline \multirow[t]{2}{*}{ No AMF } & 8.68 & $69.6 b$ & $5.7 \mathrm{~b}$ & $2.6 \mathrm{~b}$ & $3.8 \mathrm{~b}$ \\
\hline & 43.40 & $66.7 \mathrm{a}$ & $5.4 \mathrm{~b}$ & $4.6 \mathrm{c}$ & $4.3 \mathrm{c}$ \\
\hline \multirow[t]{2}{*}{ AMF } & 8.68 & $76.4 \mathrm{~d}$ & $4.3 \mathrm{a}$ & $1.2 \mathrm{a}$ & $3.2 \mathrm{a}$ \\
\hline & 43.40 & $73.7 \mathrm{c}$ & $4.4 \mathrm{a}$ & $1.2 \mathrm{a}$ & $3.4 \mathrm{a}$ \\
\hline \multicolumn{6}{|c|}{ Significance (main effects) } \\
\hline Mycorrhization & & $* * *$ & $* * *$ & $* * *$ & $* * *$ \\
\hline P level & & $* * *$ & n.s. & $* * *$ & $* *$ \\
\hline Myc. x P level & & n.s. & n.s. & $* * *$ & n.s. \\
\hline
\end{tabular}

Values followed by the same letter are not significantly different according to the Duncan test $(\mathrm{P}<0.05)$

***, **, n.s. Significant at $\mathrm{P}<0.01, \mathrm{P}<0.05$, not significant, respectively. ${ }^{1} 5$ - very good plants, 1 - unsaleable plants

root system ( $\mathrm{Peng}$ et al. 1993). In field cultivation mycorrhizal roots can explore more soil volume than non-mycorrhizal ones, due to their extramatrical hyphae (S a w a ki and S a i to, 2001); it is impossible in pot culture in very limited volume of growing media. Results obtained on Typha latifolia (D u $\mathrm{n} \mathrm{h}$ a m et al. 2003) also suggest that under greenhouse conditions, AMF act to reduce plant growth despite increased mineral nutrition and photosynthetic activity.

Mycorrhization delayed flowering of China aster, high $\mathrm{P}$ level slightly accelerated it (Tab. 2). Mycorrhizal plants had fewer flower buds and flowers than nonmycorrhizal ones. High P level increased the number of flowers of nonmycorrhizal plants only. Mycorrhization decreased visual evaluation scores of plants at the end of production in the greenhouse. A positive effect of mycorrhization on flower initiation time and flower number of China aster grown in field conditions was reported by $\mathrm{Gaur}$ and $\mathrm{Adholeya}$ (2005). Summarizing, in greenhouse conditions the effect of mycorrhization on China aster growth and flowering was not beneficial, probably due to hyphae development at the expense of the host plant. The negative effect of mycorrhization on plant growth in greenhouses can be diminished or even overcome by $\mathrm{CO}_{2}$ enrichment ( $\mathrm{N}$ o w a k, 2004 b). One must not discount the beneficial effects AMF may have upon further plant growth and health in outdoor conditions.

\section{CONCLUSIONS}

1. China aster root colonization by AMF during cultivation on ebb-and-flow benches is possible under both low and high $\mathrm{P}$ levels in nutrient solution.
2. AMF inoculation decreased growth of China aster and delayed flowering time.

3. Inoculation with AMF increased $P$ content of China aster leaves of plants grown under low P level, and $\mathrm{Mg}$ content in leaves of plants grown in both $\mathrm{P}$ levels.

4. Inoculation with AMF decreased the $\mathrm{pH}$ and slightly lowered salt accumulation in growing media.

\section{REFERENCES}

A u g z R. M. 2000. Stomatal behavior of arbuscular mycorrhizal plants. [In:] Arbuscular mycorrhizas: physiology and function. Kapulnik Y., Douds D. D. Jr. (eds.), Kluwer Academic Publishers, Dortrecht, The Netherlands: 201-237.

Clark R. B., Zeto S. K. 2000. Mineral acquisition by arbuscular mycorrhizal plants. J. Plant Nutr.: 23

Douds jr. D. D., Johns on C. R., Koch K. E. 1988. Carbon cost of the fungal symbiont relative to net leaf $\mathrm{P}$ accumulation in a split-root VA mycorrhizal symbiosis. Plant Physiol. 86: 491-496.

D unh a m R. M., R ay A. M., In ouye R. S. 2003. Growth, physiology, and chemistry of mycorrhizal and nonmycorrhizal Typha latifolia seedlings. Wetlands, 23 (4): 890-896.

Entry J. A., Rygiewicz P. T., Watrud L. S., Donnelly P. K. 2002. Influence of adverse soil conditions on the formation and function of arbuscular mycorrhizas. Adv. Environ. Res. 7 (1): 123-138.

Gaur A., Adholeya A. 2005. Diverse response of five ornamental plant species to mixed indigenous and single isolate arbuscular-mycorrhizal inocula in marginal soil amended with organic matter. J. Plant Nutr. 28: 707723. 
Ge orge E. 2000. Nutrient uptake. [In:] Arbuscular mycorrhizas: physiology and function. Kapulnik Y. and Douds D. D. Jr. (eds.), Kluver Academic Publishers, Dortrecht, The Netherlands: 307-343.

Koide, R. T., Landher r, L. L., B esmer, Y. L., Detweile r, J. M., and Holcomb, E. J. 1999. Strategies for mycorrhizal inoculation of six annual bedding plant species. Hort Science, 34: 1217-1220.

Li X. L., George E., Marschner H., 1991. Phosphorus depletion and $\mathrm{pH}$ decrease at the root-soil and hyphaesoil interfaces of VA mycorrhizal white clover fertilized with ammonium. New Phytol. 119: 397-404.

Linderman R. G., D a vis E. A. 2004. Varied response of marigold (Tagetes spp.) genotypes to inoculation with different arbuscular mycorrhizal fungi. Scientia Horticulturae, 99 (1): 67-78.

Nowak J. 2004 a. $\mathrm{CO}_{2}$ enrichment and mycorrhizal effects on root growth and some physiological traits of cuttings during rooting. Proc. International Congress Rhizosphere 2004. Perspectives and challenges. Munich, Germany, 12-17. September, 2004, PAS 4/15.

Nowak J. 2004 b. Effects of arbuscular mycorrhizal fungi and organic fertilization on growth, flowering, nutrient uptake, photosynthesis and transpiration of geranium (Pelargonium hortorum L.H. Bailey 'Tango Orange'). Symbiosis, 37: 259-266.

N ow o s i e ls k i, O., 1989. Zasady opracowywania zaleceń nawozowych. Państwowe Wydawnictwo Rolnicze i Leśne, Warszawa, Poland.

Peng S., Eissenstat D. M., Graham J. H., Williams K., Hodge N. C. 1993. Growth depression in mycorrhizal Citrus at high-phosphorus supply. Plant Physiol. 101: 1063-1071.

Phillips, J. M., And Hayman, D. S. 1970. Improved procedures for clearing roots and staining parasitic and vesicular-arbuscular mycorrhizal fungi for rapid assessment of infection. Transactions of the British Mycological Society, 55: 150-160.

S awaki H., S a ito M. 2001. Expressed genes in the extraradical hyphae of an arbuscular mycorrhizal fungus, Glomus intraradices, in the symbiotic phase. FEMS Microbiology Letters, 195: 109-113.

\section{Wpływ mikoryzacji i nawożenia fosforem na zawartość składników mineralnych, wzrost i kwitnienie astra chińskiego (Callistephus chinensis (L.) Nees) uprawianego na stołach zalewowych}

\section{Streszczenie}

Badano wpływ nawożenia fosforem i inokulacji grzybami mikoryzowymi na zawartość składników mineralnych w liściach, wzrost i kwitnienie astra chińskiego (Callistephus chinensis (L.) Nees) 'Milady' uprawianego na stołach zalewowych. Zastosowano dwa stężenia $\mathrm{P}$ w pożywce: 8,68 i 43,40 $\mathrm{mg} \times \mathrm{dm}^{-3}$. Korzenie roślin zostały zasiedlone przez grzyby mikoryzowe po miesiącu od inokulacji. Korzenie roślin nawożonych pożywką zawierającą $8,68 \mathrm{mg} \times \mathrm{dm}^{-3}$ zostały zasiedlone w 67\%, a nawożonych 43,40 mg $\times \mathrm{dm}^{-3} \mathrm{w} 60 \%$. Korzenie roślin kontrolnych nie zostały zasiedlone. Stwierdzono nieco wyższą zawartość $\mathrm{P}$ w liściach roślin zmikoryzowanych nawożonych pożywką zawierającą mniej P. Mikoryzacja nie wpływała na zawartość $\mathrm{P}$ w liściach roślin uprawianych przy wyższym poziomie $\mathrm{P}$ w pożywce. Rośliny zmikoryzowane miały więcej Mg w liściach, niezależnie od stężenia P w pożywce. Mikoryzacja nie wpływała na zawartość N, K i Ca w liściach, niezależnie od poziomu P. Poziom P nie wpływał także na zawartość tych składników w liściach. Mikoryzacja obniżała pH podłoża i zawartość rozpuszczalnych soli w podłożu, przy obu poziomach P. Rośliny inokulowane miały mniejszą świeżą masę, mniej pędów i były niższe niż nieinokulowane. Mikoryzacja opóźniała kwitnienie, niezależnie od poziomu $\mathrm{P}$. Wyższy poziom $\mathrm{P}$ trochę je przyspieszał. Wyższy poziom $\mathrm{P}$ zwiększał liczbę kwiatów u roślin niezmikoryzowanych. 